\title{
The Effect of Learning Style on Students' Learning Performance During the Covid-19 Pandemic
}

\author{
Sri Wilda Albeta ${ }^{*}$, Sri Haryati ${ }^{1,}$ Dedi Futra ${ }^{1}$, Riri Aisyah $^{2}$, and Anggi Desviana \\ Siregar ${ }^{3}$ \\ ${ }^{1}$ Department of Chemistry Education, Universitas Riau, Bina Widya Campus Km \\ 12,5 Simpang Baru, Pekanbaru, 28293, Indonesia \\ ${ }^{2}$ Department of Chemistry Education, Universitas Islam Negeri Sunan Gunung \\ Djati, Jl. A.H. Nasution No. 105, Cipadung, Kec. Cibiru, Bandung, 40614, Indonesia \\ ${ }^{3}$ Department of Chemistry Education, Institut Agama Islam Negeri Kerinci, $\mathrm{Jl}$. \\ Kapten Muradi, Kec. Sungai Liuk. Kota Sungai Penuh, Jambi, 37112, Indonesia \\ "E-mail: wilda.albeta@lecturer.unri.ac.id
}

Received: 25 May 2021; Accepted: 21 June 2021; Published: 30 June 2021

\begin{abstract}
The research aims to determine the effect of learning style on students' performance through online learning during the Covid-19 pandemic. The subjects of study are 269 chemistry education students at three universities in Indonesia. The data collection of learning style uses a Likert scale questionnaire, and learning performance is obtained from students' grade point average. In this research, students' learning style was divided into visual, auditorial, and kinesthetic. Data were analyzed using descriptive statistics with linear regression and ANOVA tests. The learning styles positively affect student learning performance by $4.7 \%$, while $95.3 \%$ of other factors are not examined in this study. The learning performance of students with auditory is higher than visual and kinesthetic learning styles. Based on the inferential analysis, there is no significant difference in student learning performance based on student learning styles. Therefore, students with different learning styles have the same learning performance in online learning.
\end{abstract}

Keywords: covid-19 pandemic, learning performance, learning style, online learning

DOI: http://doi.org/10.15575/jtk.v6i1.12603

\section{Introduction}

The world community has been shocked by Covid-19 pandemic. Indonesia is one of the countries affected by this epidemic. The government prohibits all activities involving big crowds. Based on data obtained by UNESCO (2020) to date, 69 countries in Asia, Africa, Europe, Australia, and America have restricted learning in schools and universities and carried out online or on the network learning. Through Circular Indonesian government prohibits universities from conducting face-to-face lectures and orders them to conduct online learning (Kemdikbud, 2020). Nevertheless, educators continue their role in guiding students to master the learning material even though they are not directly face-to-face with students (Adnan \& Anwar, 2020; Mailizar et al., 2020; Zaharah et al., 2020).

Online Learning aims to provide learning services to educators and students. Technological development in the world of education can be felt in the online learning process. Communication between educators and student can run optimally with the help of Information and Communication Technology 
S. W. Albeta, S. Haryati, D. Futra, R. Aisyah \& A. D. Siregar

(ICT) (Copriady, 2015; Gleason, 2020; Munir, 2010; Redecker et al., 2011; Suryadi, 2007). Several publications have developed extensive online learning in universities (Han \& Shin, 2016; Joksimović et al., 2015; Rosli et al., 2015; Wei et al., 2015). The implementation of online learning such as mobile learning systems on student academic achievement (Han \& Shin, 2016) analyzes the interaction of online learning on academic scores (Joksimović et al, 2015) and the effect of student perceptions of online learning measured based on learning achievement (Wei et al., 2015).

The educational process consists of three elements, input-process-output. Among the three elements, the learning process will determine whether the ability and learning outcomes of students are good or not. The success of the learning process will certainly be influenced by various factors, both from the school environment, family, or from students themselves. Both in terms of motivation, attitude or learning style that supports learning success (Rijal \& Bachtiar, 2015).

Learning style is one of the supports for achieving student learning performance, divided into visual, auditory, and kinesthetic. A person's learning style combines absorbing information easily, organizing, and processing that information (Bire et al., 2014; DePorter \& Hernacki, 2015). Every student uses these three styles at a certain stage, but one of the three tends to be more prominent (Bire et al., 2014). With these differences, educators must accommodate the needs of participants in the learning process activities (Sari, 2014). Therefore, educators must consider learning styles and learning strategies in selecting and designing learning materials to maximize student achievement. In the research conducted by Alnujaidi (2018), it was found that learning styles were correlated with learning strategies and suggested research regarding the relationship between learning styles and learning achievement.

During the Covid-19 pandemic, the learning was carried out online. Online learning is a new experience for the student in Indonesia. This is what underlines the researchers to
The Effect of Learning Style on Students' Learning Performance During the Covid-19 Pandemic

determine the effect of learning styles on student learning performance and determine if there are differences in student learning performances based on learning styles.

\section{Research Method}

This research uses a survey design with a questionnaire. In this research there were 269 students of chemistry education at three Universities in Indonesia that are Universitas Riau, Universitas Islam Negeri Sunan Gunung Djati, and Institut Agama Islam Negeri Kerinci. The instrument in this research is a questionnaire. Questionnaire items are arranged based on indicators of learning styles according to theoretical studies, namely visual, auditory and kinesthetic styles.

Instrument test was carried out by validity and reliability test. The instrument validity test was carried out using the product-moment correlation. The reliability test uses the Cronbach Alpha coefficient. In this study, all items are valid and reliable. The Cronbach Alpha value is 0.92 with very reliable criteria so that all statement items in the questionnaire can be used as research instruments.

The responses to the learning style questionnaire were grouped into five categories on the Likert scale (Table 1). After the student has filled out the questionnaire, the next step is to recapitulate the questionnaire to determine the learning styles used by each student during learning. Meanwhile, the learning performance is obtained from the student's GPA.

Table 1. Student Satisfaction Likert Scale

\begin{tabular}{lc}
\hline \multicolumn{1}{c}{ Category } & Score \\
\hline Strongly agree & 5 \\
Agree & 4 \\
Undecided & 3 \\
Disagree & 2 \\
Strongly disagree & 1 \\
\hline
\end{tabular}

Data analysis in this research used descriptive statistics and parametric inferential. In this research, there are two hypotheses: 
S. W. Albeta, S. Haryati, D. Futra, R. Aisyah \& A. D. Siregar

$\mathrm{H}_{\mathrm{a1}}$ : there is an effect of learning style on student learning performance in online learning.

$\mathrm{H}_{\mathrm{a} 2}$ : there are differences in learning performance based on student learning style in online learning.

Inferential statistical analysis used is linear regression test and Anova with the help of SPSS 20 for windows. A linear regression test was carried out to determine the effect of learning styles on learning performance in online learning $\left(\mathrm{H}_{\mathrm{a} 1}\right)$. Anova test was carried out to determine differences in learning performances based on student learning styles in online learning.

\section{Result and Discussion}

The learning styles in this research are divided into three, visual, auditory and kinesthetic.
The Effect of Learning Style on Students' Learning Performance During the Covid-19 Pandemic

Figure 1 shows the average learning performance of visual, auditory, and kinesthetic learning styles: 3.562, 3.568, and 3.531 , respectively. Students who study with an auditory learning style are easier to receive information during online learning. This is because they are more active in interacting discussions. This is in line with the opinion of Bire et al. (2014), which states that students who use auditory learning styles tend to be easier to digest, process and convey information by listening directly. In addition, during the Covid-19 pandemic, online learning is more dominant in delivering information via audio, making it easier for students who have an auditory learning style to master lecture material.

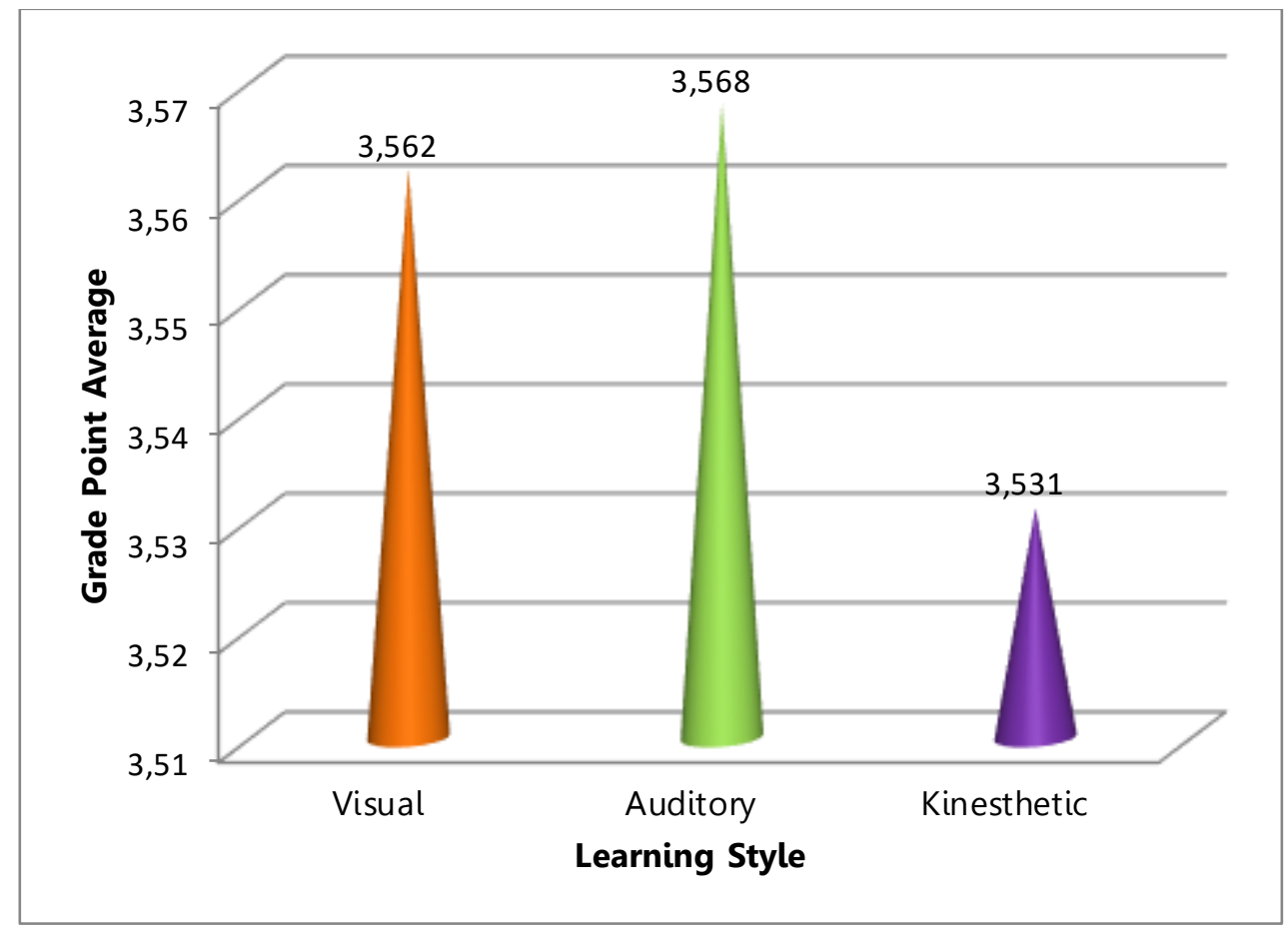

Figure 1. Average Learning Performance Based on Learning Style

Figure 2 shows that the preferred learning styles of chemistry education students are visual (35.688\%) and kinesthetic (35.688\%) learning styles. Chemistry education students enjoy learning by seeing, observing through pictures and/or demonstrations. These are the characteristics of the visual learning style. In addition, chemistry education students also 
S. W. Albeta, S. Haryati, D. Futra, R. Aisyah \& A. D. Siregar

like learning with physical activity and are directly involved in learning. These are characteristics of the kinesthetic learning style. This result aligns with Kirna (2014) that chemistry students prefervisual learning styles
The Effect of Learning Style on Students' Learning Performance During the Covid-19 Pandemic

and are active in learning. The same result was also obtained by Ibrahim and Hussein (2016) also Özbaş (2013) that the learning styles favored by students are visual and kinesthetic.

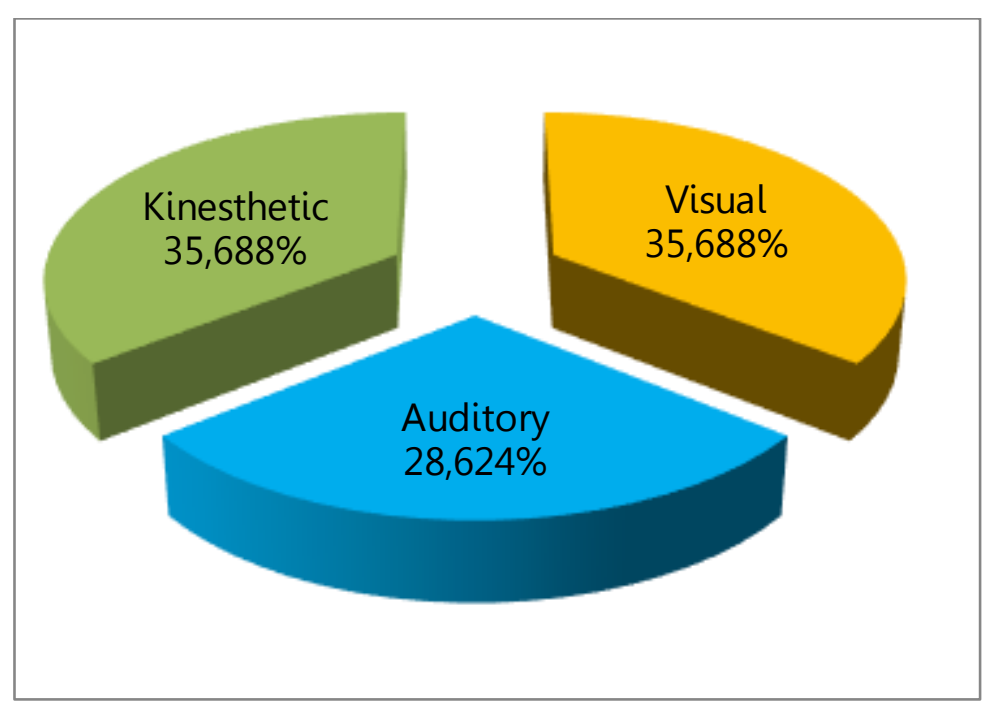

Figure 2. Percentage Diagram of Student Learning Style Tendency

Students who have a visual learning style will quickly learn and understand the information or subject matter presented in writing. It can be in the form of charts, pictures, graphs that involve their eyesight. At the same time, the kinesthetic learning style tends to learn with movement or learn by doing directly (Ahmadi \& Supriyono, 2004; DePorter \& Hernacki, 2015). This research found that visual and kinesthetic learning styles are the preferred learning styles for chemistry education students. However, visual and kinesthetic learning styles have lower learning performance compared to auditory learning styles. This means that lecturers must pay attention to student learning styles so that teaching strategies appear following the learning styles that students prefer, this result is confirmed by Aqel and Mahmoud (2006). Furthermore, there is a significant difference in student learning styles based on the academic level, so lecturers must consider teaching methods or teaching strategies according to student learning styles. Through these results, chemistry education lectures can consider strategies or media in online according to visual and kinesthetic learning styles. This result is also confirmed by Tseng et al. (2008) that learning styles show the way and one's pleasure in learning and can be a means for educators to adapt individually to students so that learning objectives can be achieved properly.

Furthermore, inferential analysis is needed to determine the effect of learning styles on learning performance and differences in learning performances based on learning styles. This research uses parametric inferential analysis so that before the data is analyzed, prerequisite tests are conducted first. Learning performance must meet the prerequisites of normality and homogeneity. The descriptive analysis of the KolmogorovSmirnov test was analyzed to determine the normality of the data. Table 2 shows the analysis results show that each significant value of learning style is 0.2 and learning 
S. W. Albeta, S. Haryati, D. Futra, R. Aisyah \& A. D. Siregar

performance is 0.17 . The significance value of learning style and learning performance is > 0.05 , meaning that the data is normally distributed. The principle of the normality test using the Kolmogorov-Smirnov is to find the largest deviation (D) from the cumulative distribution function of the observation data (empirical) to the theoretical cumulative distribution function. If the maximum deviation formed is not too large, the observation data can be categorized as normally distributed (Nasrum, 2018).

Table 2. The Normality of learning Styles and Learning Performance

\begin{tabular}{lcc}
\hline \multicolumn{1}{c}{ Variable } & df & Sig \\
\hline Learning Style & 269 & 0.20 \\
Learning Performance & 269 & 0.17 \\
\hline
\end{tabular}

The homogeneity test was conducted to determine the similarity of variance. In this research, the homogeneity test was carried out for learning performance data. This test is a prerequisite for the Anova test, which aims to determine differences in learning performance based on learning styles. Table 3 show the significant value of learning performance is 0.197 . Thus the value of sig $>0.05$ so that the data in this study is homogeneous.

Table 3. Homogeneity Test Results

\begin{tabular}{cccc}
\hline $\begin{array}{c}\text { Levene } \\
\text { Statistics }\end{array}$ & df1 & df2 & Sig \\
\hline 1.632 & 2 & 266 & 0.197 \\
\hline
\end{tabular}

The prerequisite tests for normality and homogeneity are met, so that parametric inferential tests can be performed, which is linear regression and Anova tests. The linear regression test was carried out to determine the effect of learning styles on student learning performance during the Covid-19 pandemic. The results of the linear regression test are shown in Table 4.
The Effect of Learning Style on Students' Learning Performance During the Covid-19 Pandemic

Table 4. Linear Regression Test Results

\begin{tabular}{lrrrrr}
\hline \multirow{2}{*}{ Model } & \multicolumn{2}{c}{ Coefficients } & & & \\
\cline { 2 - 4 } & B & $\begin{array}{c}\text { Std. } \\
\text { Error }\end{array}$ & T & Sig. & R Squ \\
\hline (Constant) & 2.975 & 0.159 & 18.66 & 0.0 & 0.047 \\
Learning & 0.012 & 0.003 & 3.65 & 0.0 & \\
Style & & & & & \\
\hline
\end{tabular}

Learning styles affect student learning performance during the Covid-19 pandemic. This is based on the results of the regression test shown in Table 4. Where the value of sig $(0.0)<0.05$, it can be concluded that $\mathrm{H}_{\mathrm{a} 1}$ is accepted, so that there is a significant effect of learning style on learning performance. This finding is in line with the research of Bire et al. (2014) visual, auditory and kinesthetic learning styles affect learning outcomes. This finding is also confirmed by Shaw (2012) that learning styles have a significant effect on students' learning performance on online forums. In addition, according to Alnujaidi (2018), learning style is an important thing to consider in maximizing student learning achievement.

Table 4 explains the linear regression equation $y=2.975+0.012 x$. If there is no learning style $(\mathrm{x})$, then the consistent value of learning performance $(y)$ is 2.975 and learning style positively affects the learning performance of $4.7 \%$. In comparison, $95.3 \%$ is influenced by other factors not examined in this study. Magdalena (2015) confirmed this result, which states that learning performance can be achieved from several factors other than learning styles, namely personality factors, cognitive factors, motivational factors, and others not considered. This result is in line with Marpaung (2015) opinion that learning style is one of the non-intellectual factors that are part of internal factors that can affect learning achievement. In addition, there are external factors that also affect learning achievements, such as social factors, cultural factors, physical environmental factors and spiritual 
S. W. Albeta, S. Haryati, D. Futra, R. Aisyah \& A. D. Siregar

environment, which were not examined in this research.

Table 5. Anova Test Results

\begin{tabular}{lcccc}
\hline & $\begin{array}{c}\text { Sum of } \\
\text { Squares }\end{array}$ & df & F & Sig. \\
\hline $\begin{array}{l}\text { Between } \\
\begin{array}{l}\text { Groups } \\
\text { Within } \\
\text { Groups }\end{array}\end{array}$ & 0.073 & 2 & 0.383 & 0.682 \\
\hline
\end{tabular}

Student learning styles are divided into three, visual, auditory and kinesthetic. Table 5 show the data analysis result with the Anova test; the value of sig $(0.682)>0.05 \mathrm{H}_{\mathrm{a} 2}$ was rejected, it can be concluded that there is no significant difference in learning performance during the Covid-19 pandemic based on student learning styles. Descriptively, auditory learning styles have an average higher performance than visual and kinesthetic learning styles. Students as learners have a preferred way of processing information or knowledge. Each student's learning style will be different even though their goal is the same: to obtain maximum learning performance. This study found that students' learning performance did not differ significantly even though students' learning styles were different. This finding supports the findings of Demirbas and Demirkan (2007). Although students have their ways and different learning styles, their goal is to achieve learning performance. In addition, according to Chatib (2012), learning style is an influential provision for students in the learning process. Therefore, if students know their learning style characteristics, they will be more easily to motivated in learning.

Learning is generally an individual activity to seek and obtain knowledge, experience and information through learning materials or the environment. A person uses different learning methods to gain knowledge and requires the ability to sense, remember, think and solve problems. Online learning during the Covid-
The Effect of Learning Style on Students' Learning Performance During the Covid-19 Pandemic

19 pandemic is a new experience for students. Students' ability to adapt to new conditions is important because there is no difference in learning performance even though students' learning styles are different. This result is also confirmed by Maric et al. (2015), which states that good knowledge about learning can make students adapt to the learning environment.

This research was conducted during the Covid-19 pandemic, where learning was carried out online. Although respondents in this study were students in science, namely chemistry education, this is a limitation, so further research is recommended to expand the respondent's scientific field, namely science and social science.

\section{Conclusion}

Student learning styles in this study were divided into three, visual, auditory and kinesthetic. During the Covid-19 pandemic, students studied online which was a new experience for students. Learning styles affect student learning performance significantly when learning is carried out online. Learning style positevely affects student learning performance by $4.7 \%$, while $95.3 \%$ of other factors are not examined in the study. Although, students' learning performance with auditory learning styles is higher than those with visual and kinesthetic learning styles. Therefore, students with different learning styles have the same learning performance in online learning that was carried out during the Covid-19 pandemic. Another result of this research is that chemistry education students enjoy visual and kinesthetic learning styles.

\section{Acknowledgement}

This research was conducted with the help of funds from DIPA LPPM Universitas Riau in 2021, through a research grant No.598/UN19.5.1.3/PT.01.03/2021. Thus, we 
S. W. Albeta, S. Haryati, D. Futra, R. Aisyah \& A. D. Siregar

would like to thank the chairman of LPPM Universitas Riau.

\section{References}

Adnan, M., \& Anwar, K. (2020). Online learning amid the COVID-19 pandemic: students' perspectives. Journal of Pedagogical Sociology and Psychology, 2(1), 2-8. https://doi.org/10.33902/JPSP. 2020261309

Ahmadi, H. A., \& Supriyono, W. (2004). Psikologi belajar (Revisi). PT. Rineka Cipta.

Alnujaidi, S. (2018). The relationship between EFL students' perceptual learning styles and their language learning strategies in Saudi Arabia. International Journal of English Linguistics, 9(1), 69. https://doi.org/10.5539/ijel.v9n1p69

Aqel, F., \& Mahmoud, S. (2006). Learning styles of an-najah national university students in learning english as a foreign language. An - Najah Univ. J. Res. (Humanities), 20(2), 597-624. Retrieved from https://staff-

old.najah.edu/sameer/publishedresearch/learning-styles-najah-nationaluniversity-students-learning-englishforeig

Bire, A. L., Geradus, U., \& Bire, J. (2014). Pengaruh gaya belajar visual, auditorial, dan kinestetik terhadap prestasi belajar siswa. Jurnal Kependidikan, 44(2), 168174.

https://doi.org/10.21831/jk.v44i2.5307

Chatib, M. (2012). Orangtuanya manusia: melejitkan potensi dan kecerdasan dengan menghargai fitrah setiap anak. PT. Mizan Pustaka.

Copriady, J. (2015). Self - motivation as a mediator for teachers' readiness in applying ICT in teaching and learning. Turkish Online Journal of Educational Technology, 13(4), 115-123.
The Effect of Learning Style on Students' Learning Performance During the Covid-19 Pandemic

https://doi.org/10.1016/j.sbspro.2015.01. 529

Demirbas, O. O., \& Demirkan, H. (2007). Learning styles of design students and the relationship of academic performance and gender in design education. Learning and Instruction, 17(3), 345-359. https://doi.org/10.1016/j.learninstruc.20 07.02.007

DePorter, B., \& Hernacki, M. (2015). Quantum learning: membiasakan belajar nyaman dan menyenangkan (Translate: Alwiyah Abdurrahman \& Sari Meutia; ed. 1). Kaifa.

Gleason, B. (2020). Expanding interaction in online courses: integrating critical humanizing pedagogy for learner success. Educational Technology Research and Development. https://doi.org/10.1007/s11423-02009888-w

Han, I., \& Shin, W. S. (2016). The use of a mobile learning management system and academic achievement of online students. Computers and Education, 102, 79-89.

https://doi.org/10.1016/j.compedu.2016. 07.003

Ibrahim, R. H., \& Hussein, D. (2016). Assessment of visual, auditory, and kinesthetic learning style among undergraduate nursing students. Publisher of International Academic Journals, 5(1), 1-4. https://doi.org/10.14419/ijans.v5i1.5124

Joksimović, S., Gašević, D., Kovanović, V., Riecke, B. E., \& Hatala, M. (2015). Social presence in online discussions as a process predictor of academic performance. Journal of Computer Assisted Learning, 31(6), 638-654. https://doi.org/10.1111/jcal.12107

Kemdikbud. (2020). Surat edaran kemendikbud no.4 tahun 2020 (p. 300). Retrieved 
S. W. Albeta, S. Haryati, D. Futra, R. Aisyah \& A. D. Siregar

http://pgdikmen.kemdikbud.go.id/readnews/surat-edaran-mendikbud-nomor4-tahun-2020

Kirna, I. M. (2014). Pengembangan konten online untuk mendukung blended learning pada perkuliahan kimia kuantum dasar. Cakrawala Pendidikan, 33(2), 186197.

https://doi.org/10.21831/cp.v2i2.2146

Magdalena, S. M. (2015). The relationship of learning styles, learning behaviour and learning outcomes at the romanian students. Procedia - Social and Behavioral Sciences, 180, 1667-1672. https://doi.org/10.1016/j.sbspro.2015.05. 062

Mailizar, Almanthari, A., Maulina, S., \& Bruce, S. (2020). Secondary school mathematics teachers ' views on e-learning implementation barriers during the Covid-19 pandemic: the case of indonesia. EURASIA Journal of Mathematics, Science and Technology Education, 16(7). https://doi.org/10.29333/ejmste/8240

Maric, M., Penger, S., Todorovic, I., Djurica, N., \& Pintar, R. (2015). Differences in learning styles: a comparison of slovenian universities. Procedia - Social and Behavioral Sciences, 197, 175-183. https://doi.org/10.1016/j.sbspro.2015.07. 079

Marpaung, J. (2015). Pengaruh gaya belajar terhadap prestasi belajar siswa. KOPASTA: Journal of the Counseling Guidance Study Program, 2(2). https://doi.org/10.33373/kop.v2i2.302

Munir, M. (2010). Penggunaan learning management system (lms) di perguruan tinggi: studi kasus di Universitas Pendidikan Indonesia. Jurnal Cakrawala Pendidikan, 1(1), 109-119. https://doi.org/10.21831/cp.v1i1.222

Nasrum, A. (2018). Uji normalitas data untuk penelitian. Jayapangus Press Books, i-
The Effect of Learning Style on Students' Learning Performance During the Covid-19 Pandemic

117.

Özbaş, S. (2013). The investigation of the learning styles of university students. Online Journal of New Horizons in Education, 3(1), 53-58. Retrieved from http://www.crlt.umich.edu/sites/default/f iles/resource_files/CRLT_no10.pdf

Redecker, C., Leis, M., Leendertse, M., Punie, Y., Gijsbers, G., Kirschner, P., Stoyanov, S., \& Hoogveld, B. (2011). The future of learning: preparing for change publication. In Publications Office of the European Union. https://doi.org/10.2791/64117

Rijal, S., \& Bachtiar, S. (2015). Hubungan antara sikap, kemandirian belajar, dan gaya belajar dengan hasil belajar kognitif siswa. Jurnal Bioedukatika, 3(2), 15. https://doi.org/10.26555/bioedukatika.v 3i2.4149

Rosli, M. S., Saleh, N. S., Aris, B., Ahmad, M. H., Sejzi, A. A., \& Shamsudin, N. A. (2015). Elearning and social media motivation factor model. International Education Studies, 9(1), 20. https://doi.org/10.5539/ies.v9n1p20

Sari, A. K. (2014). Analisis karakteristik gaya belajar VAK (visual, auditorial, kinestetik) mahasiswa pendidikan informatika angkatan 2014. Jurnal Ilmiah Edutic, 1(1), 1-12.

https://doi.org/10.21107/edutic.v1i1.395

Shaw, R. S. (2012). A study of the relationships among learning styles, participation types, and performance in programming language learning supported by online forums. Computers and Education, 58(1), 111-120.

https://doi.org/10.1016/j.compedu.2011. 08.013

Suryadi, A. (2007). Pemanfaatan ict dalam pembelajaran. Pendidikan Terbuka dan Jarak Jauh, 8(1), 6. Retrieved from http://simpen.lppm.ut.ac.id/ptjj/PTJJ\%20 Vol\%208.2\%20september\%202007/01- 
S. W. Albeta, S. Haryati, D. Futra, R. Aisyah \& A. D. Siregar

acesuryadi.pdf

Tseng, J. C. R., Chu, H. C., Hwang, G. J., \& Tsai, C. C. (2008). Development of an adaptive learning system with two sources of personalization information. Computers and Education, 51(2), 776-786. https://doi.org/10.1016/j.compedu.2007. 08.002

United Nation of Educational Scientific and Culture Organization (UNESCO). (2020). Covid-19 impact on education. Retrieved from https://en.unesco.org/Covid19/educatio nresponse

Wei, H. C., Peng, H., \& Chou, C. (2015). Can more interactivity improve learning achievement in an online course? Effects of college students' perception and actual use of a course-management system on their learning achievement. Computers and Education, 83, 10-21. https://doi.org/10.1016/j.compedu.2014. 12.013

Zaharah, Kirilova, G. I., \& Windarti, A. (2020). Dampak wabah virus corona terhadap kegiatan belajar mengajar di Indonesia. Salam: Jurnal Sosial Dan Budaya Syar'i, $7(3)$, 269-282. https://doi.org/10.15408/sjsbs.v7i3.1510 4
The Effect of Learning Style on Students' Learning Performance During the Covid-19 Pandemic 